\title{
Diet of a specialist in a changing environment: the crabeater seal along the western Antarctic Peninsula
}

\author{
L. A. Hückstädtt ${ }^{1, *}$, J. M. Burns ${ }^{2}$, P. L. Koch ${ }^{3}$, B. I. McDonald ${ }^{4}$, D. E. Crocker ${ }^{5}$, D. P. Costa ${ }^{6}$ \\ ${ }^{1}$ Ocean Sciences Department, University of California Santa Cruz, Santa Cruz, California 95060, USA \\ ${ }^{2}$ Department of Biological Sciences, University of Alaska, Anchorage, Alaska 99508, USA \\ ${ }^{3}$ Earth and Planetary Sciences Department, University of California Santa Cruz, Santa Cruz, California 95064, USA \\ ${ }^{4}$ Center for Marine Biotechnology and Biomedicine, Scripps Institution of Oceanography, La Jolla, California 92037, USA \\ ${ }^{5}$ Department of Biology, Sonoma State University, Rohnert Park, California 94928, USA \\ ${ }^{6}$ Ecology and Evolutionary Biology Department, University of California Santa Cruz, Santa Cruz, California 95060, USA
}

\begin{abstract}
Although crabeater seals Lobodon carcinophaga are among the most abundant consumers of Antarctic krill Euphausia superba, their diet has rarely been studied throughout most of the species' range. Using $\delta^{13} \mathrm{C}$ and $\delta^{15} \mathrm{~N}$ values in vibrissae from 53 seals, we examined the trophic ecology of crabeater seals from the western Antarctic Peninsula (wAP) in 2001, 2002 and 2007. We observed a wide variability in individual seal mean $\delta^{13} \mathrm{C}$ values, which ranged from $-19.8 \%$ to $-24.9 \%$, whereas mean $\delta^{15} \mathrm{~N}$ value varied from $5.4 \%$ to $7.9 \%$. We identified a positive significant effect of seal mass on $\delta^{13} \mathrm{C}$ values, as well as a significant seasonal effect (higher $\delta^{13} \mathrm{C}$ values in austral winter), which likely resulted from changes in the composition of the community of primary producers. $\delta^{15} \mathrm{~N}$ values for crabeater seals, on the other hand, were affected by year, with individuals in 2002 having higher $\delta^{15} \mathrm{~N}$ values. The median (with range) contribution of Antarctic krill to the diet of crabeater seals, as estimated using the Bayesian mixing model MixSIR, was $87.9 \%$ (81.2 to $94.8 \%$ ). During 2002, krill biomass in the wAP was at one of its lowest levels during the last 2 decades, coinciding with a slight reduction in the importance of krill for the diet of the seals that year, which reached $84.5 \%$ (75.1 to $92.4 \%$ ). Despite the relative plasticity observed in the diet of crabeater seals, it is unknown to what extent, and at what rate, crabeater seals might be able to switch to a more generalized diet, which might impact their fitness, given the ongoing environmental change along the wAP.
\end{abstract}

KEY WORDS: Lobodon carcinophaga · Euphausia superba · Antarctic fish · Stable isotopes · Diet · Specialization

Resale or republication not permitted without written consent of the publisher

\section{INTRODUCTION}

The western Antarctic Peninsula (wAP) is one of the most biologically productive areas of the Southern Ocean (Prezelin et al. 2000, Marrari et al. 2008). Mid-trophic level species shape the dynamics of the entire wAP ecosystem, forming 2 very distinctive trophic webs. Copepods, mesopelagic fish and squid, occupy the mid-trophic positions of the northern slope and oceanic food web along the wAP. Antarctic krill Euphausia superba is the dominant mid-trophic level species of the Southern food web in the pack ice zone, and therefore a major player in the entire ecosystem of the Southern Ocean (Kock \& Shimadzu 1994, Hofmann \& Hüsrevoglu 2003). Further, the wAP is an area of unusually high production of Antarctic krill (Atkinson et al. 2004, Howard et al. 2004, Moline et al. 2004). The large and persistent 
biomass of krill and other mid-trophic species in this region of the Southern Ocean sustains a large biomass of endothermic top predators (Costa \& Crocker 1996, Ducklow et al. 2007), possibly the most important community of endothermic top predators in the world in terms of energy flux (Croxall 1992).

The wAP is a region with one of the greatest rates of environmental warming in the world, although the impacts of such rapid change on the marine ecosystem are still unclear (Atkinson et al. 2004, Stammerjohn et al. 2008). Recent studies have linked climatic change with perturbations at different levels of the trophic web, from long-term declines in krill biomass to shifts in the range and abundance of different species of penguins (Fraser \& Hofmann 2003, Atkinson et al. 2004, Clarke et al. 2007, Costa et al. 2010). Top predators might also respond to climate change by alterations in their foraging behavior, movement patterns and at-sea distribution (Trathan et al. 2007). Because it is likely that climate change will primarily affect predators through alterations in prey distribution (Croxall 1992), shifts in the foraging behavior of top predators can provide us with an insight into the underlying changes of prey fields (Wall et al. 2007).

The crabeater seal Lobodon carcinophaga is one of the most abundant species of large mammals, with worldwide population estimates that vary between 14 and 30 million individuals (Erickson et al. 1990, Southwell et al. 2004, Knox 2007, Bengtson 2009). Endemic to Antarctic waters, the species is distributed along the coast of the continent, where it is considered a highly specialized predator of Antarctic krill, which accounts for over $90 \%$ of its diet, and the remainder made up of fish and other invertebrates (Laws 1977, Green \& Williams 1986, Zhao et al. 2004, Knox 2007). Such dietary specialization, along with its relatively high biomass, makes the crabeater seal one of the largest consumers of krill in the world (Laws 1977, Hill et al. 2006, Hewitt \& Lipsky 2009). On the other hand, however, this high level of specialization could make crabeater seals particularly vulnerable given the expected reductions in krill abundance as a result of the retreating sea ice under the current conditions of rapid climate change (Loeb et al. 1997, Stammerjohn et al. 2008).

Despite the crabeater seal's high abundance and its role as one of the most abundant consumers of Antarctic krill, there are only a handful of studies on its diet, based on stomach contents or scat analyses (Laws 1977, Green \& Williams 1986, Lowry et al. 1988, Bengtson 2009). This approach is widely used in diet studies of marine mammals due to the high likelihood of finding samples with identifiable prey and the method's low cost, but these studies provide only a snapshot view of the prey consumed (and not necessarily assimilated), and the results may be biased based on differential digestibility of prey taxa (Bowen 2000, Tollit et al. 2003). Hence, our knowledge of the variability of diets among individual crabeater seals at different temporal scales (from seasons to years) is limited or nonexistent.

Here, we present isotopic data $\left(\delta^{13} \mathrm{C}\right.$ and $\delta^{15} \mathrm{~N}$ values) from vibrissae samples collected from crabeater seals in 2001, 2002 and 2007 along the WAP, and use those data to reconstruct the diet of the species using the Bayesian mixing model MixSIR (Moore \& Semmens 2008). Stable isotopes, particularly $\delta^{13} \mathrm{C}$ and $\delta^{15} \mathrm{~N}$, are widely used in studies on feeding habits of animals (since isotopic values in a given species are correlated with those of the prey items included in its diet) and food webs (because isotopes either fractionate or change in a predictable fashion between trophic levels and thereby reflect trophic position) (Deniro \& Epstein 1978, Vander Zanden et al. 1997, Hirons et al. 2001a, Vander Zanden \& Rasmussen 2001). By measuring isotopic values along the vibrissae we (1) incorporate dietary information integrated over a time scale of months or years (Hobson et al. 1996, Hall-Aspland et al. 2005), and (2) examine within-individual variability in the diet, since vibrissae contain a time series of information for the period during which they were formed (Cherel et al. 2009, Newsome et al. 2009).

\section{MATERIALS AND METHODS}

\section{Sample collection}

Adult crabeater seals $(\mathrm{N}=53$, see Table 2) were captured in fall (March to May) and/or winter (June to August) of $2001(\mathrm{n}=14), 2002(\mathrm{n}=29)$ and 2007 ( $\mathrm{n}=10$ ) during 3 cruises to the Crystal Sound/Lau Beouf fjord/Marguerite Bay area along the wAP on board the RV 'Lawrence M. Gould' (Fig. 1). Cruises in 2001 and 2002 were part of the US Southern Ocean GLOBEC (GLOBal ocean ECosystems dynamics) program (Hofmann et al. 2004), and data on habitat use, diving and foraging behavior, and body condition of the sampled seals have been published elsewhere (see Burns et al. 2004, 2008, Gales et al. 2004, McDonald et al. 2008, Costa et al. 2010).

Animals were sighted from the bridge of the vessel and approached by foot or inflatable boat, to deliver an intramuscular injection of Telazol $(0.8$ to $1.2 \mathrm{mg}$ $\mathrm{kg}^{-1}$ body wt, in 2001) or Midazolam (0.5 to $0.75 \mathrm{mg}$ 
$\mathrm{kg}^{-1}$ body wt, in 2002 and 2007), administered via a jab-stick or dart gun to sedate each animal. After the induction, animals were manually restrained with a hoop net, and isofluorane combined with oxygen was administered via a gas mask (Gales et al. 2005). Morphometric measurements were made for each animal (mass and straight line length), and vibrissae (1 per seal) were collected by plucking them.

\section{Stable isotope analysis}

Vibrissae samples were analyzed for $\delta^{13} \mathrm{C}$ and $\delta^{15} \mathrm{~N}$ values. We followed 2 different protocols for the treatment of samples in the laboratory: (1) vibrissae from 2001 and 2002 were washed with ethanol to remove lipids, allowed to air dry for $24 \mathrm{~h}$ and then subsampled, so that an isotopic sample was collected, on average, every $0.9 \mathrm{~cm}$ (range 0.3 to $2.7 \mathrm{~cm}$ ), with masses that varied between 0.2 and $0.84 \mathrm{mg}_{\text {; }}(2)$ vibrissae from 2007 samples were washed with distilled water and a mild detergent, and allowed to air dry for at least $24 \mathrm{~h}$. A second cleaning was conducted by rinsing whole vibrissae in an ultrasonic bath for $15 \mathrm{~min}$ in petroleum ether to eliminate lipids, and then vibrissae were subsampled every $0.5 \mathrm{~cm}$, obtaining samples with masses of $0.5 \pm 0.05 \mathrm{mg}$ from the proximal end of each segment. Due to the confounding factors associated with the base of the vibrissae (Zhao et al. 2006, Hückstädt et al. 2012), we eliminated all data from this segment from analyses. Given the composition of the analyzed tissue (keratine), the lipid extraction technique is only a precautionary measure to eliminate any lipids that might have been attached during handling; thus, both approaches used in this study are appropriate, allowing us to compare the data despite the different treatment utilized.

Samples from 2001 and 2002 were analyzed using a Costech ECS4010 elemental analyzer coupled with a Finnigan Delta Plus XP mass spectrometer (Alaska Stable Isotope Facility, University of Alaska Fairbanks), while samples collected in 2007 were analyzed using a Carbo-Elba elemental analyzer interfaced with a Finnigan Delta Plus XP mass spectrometer (Light Stable Isotope Lab, University of California Santa Cruz).

The abundance of stable isotopes is expressed in $\delta$ notation, according to:

$$
\delta^{h} X=\frac{R_{\text {sample }}-R_{\text {standard }}}{R_{\text {standard }}} \times 1000
$$

where $X$ is the element, $h$ is the heavy atomic mass number, and $R$ is the heavy-to-light isotope ratio (i.e. $\left.{ }^{13} \mathrm{C} /{ }^{12} \mathrm{C},{ }^{15} \mathrm{~N} /{ }^{14} \mathrm{~N}\right)$ in the standard or sample. The $\delta^{13} \mathrm{C}$ standard is Vienna PeeDee Belemnite (VPDB), and $\delta^{15} \mathrm{~N}$ standard is atmospheric nitrogen $\left(\mathrm{N}_{2}\right)$. The units are parts per thousand (\%) deviations from the standard. The experimental precision, estimated as the standard deviation of replicates of within-run standards (peptone for 2001-2002 samples, gelatin for 2007 samples), was $0.1 \%$ for $\delta{ }^{13} \mathrm{C}$ values and $0.2 \%$ for $\delta{ }^{15} \mathrm{~N}$ values (2001-2002), and $0.1 \%$ for $\delta{ }^{13} \mathrm{C}$ and $0.1 \%$ for $\delta{ }^{15} \mathrm{~N}$ values (2007).

\section{Data analysis}

To investigate if there were effects of year, season, sex or body mass on vibrissae isotopic values, we used a suite of linear mixed models with 'individual' as random effect using the package 'nlme' in R (Pinheiro et al. 2011), followed by a mixed model variance component analysis (MMVCA) using 'ape' in R (Paradis et al. 2004), to estimate the percentage of observed variability associated with between- versus within-individual components. We selected the optimal model for each isotopic system (i.e. $\delta^{13} \mathrm{C}$ or $\delta^{15} \mathrm{~N}$ ) using the likelihood ratio test (Zuur et al. 2009).

To analyze the contribution of prey items to the diet of crabeater seals, we used the Bayesian isotopic mixing model MixSIR v1.0 (Moore \& Semmens 2008, Semmens \& Moore 2008). A Bayesian approach is advantageous, since it allows for the estimation of the distributions of posterior probabilities for the proportional contributions of sources (i.e. prey items) to the mix (i.e. the consumer) through numerical integration (Semmens \& Moore 2008), while incorporating uncertainties in the tissuespecific trophic discrimination factors (Martinez del Rio et al. 2009), as well as the uncertainty in consumer and prey isotopic data.

Previous studies have described the crabeater seal diet very broadly, only identifying prey as krill, fish and squid (e.g. Laws 1977, Green \& Williams 1986, Lowry et al. 1988), and consequently we used noninformative source contribution priors when running the mixing model, using a number of iterations sufficient to render $>10000$ samples in the posterior distributions of the source contributions to the diet. In our study, we included published isotopic data for Antarctic krill, the nototheniid Pleurogramma antarcticum, and the myctophids Electrona antarctica and E. carlsbergi from the study area (Polito \& Goebel 2010, Polito et al. 2011, our Table 1), as these prey have been observed in diets of other top preda- 


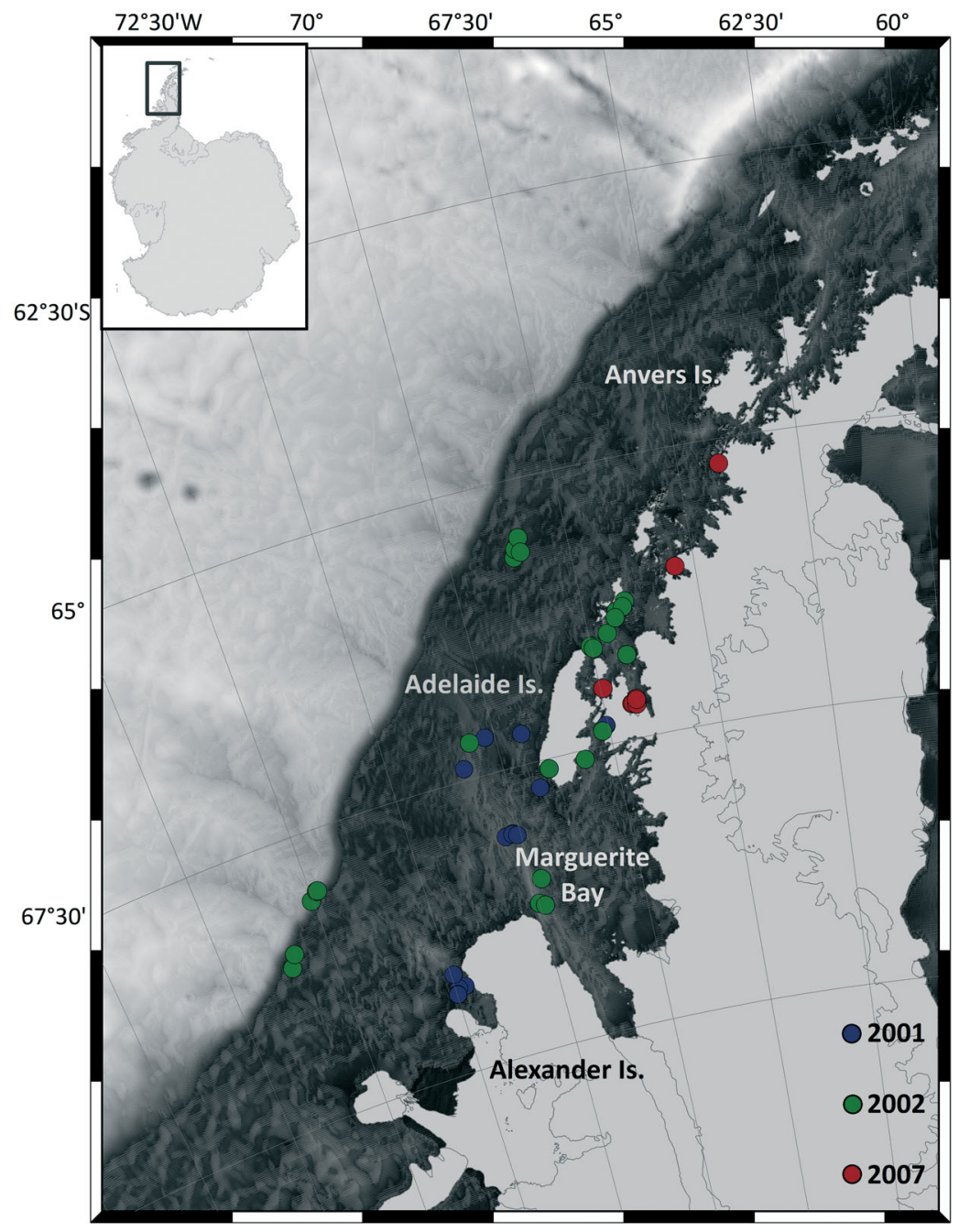

Fig. 1. Lobodon carcinophaga. Capture sites of crabeater seals along the western Antarctic Peninsula. Adult crabeater seals were captured in 2001 ( $\mathrm{n}=14$, blue), $2002(\mathrm{n}=29$, green) and 2007 ( $\mathrm{n}=10$, red) during different fallwinter cruises. Dark shading: continental shelf

Table 1. $\delta^{13} \mathrm{C}$ and $\delta^{15} \mathrm{~N}$ values (mean $\pm \mathrm{SD}$ ) of potential prey for crabeater seal Lobodon carcinophaga along the western Antarctic Peninsula

\begin{tabular}{|llll|}
\hline Prey & $\delta^{13} \mathrm{C}(\%)$ & $\delta^{15} \mathrm{~N}(\%)$ & Source \\
\hline Krill & & & \\
$\quad$ Euphausia superba & $-26.2 \pm 0.9$ & $3.2 \pm 0.7$ & Polito et al. (2011) \\
Fish & & & \\
Pleuragramma antarcticum & $-24.7 \pm 0.4$ & $9.4 \pm 0.5$ & Polito et al. (2011) \\
Electrona antarctica & $-25.1 \pm 0.9$ & $9.4 \pm 0.6$ & Polito \& Goebel (2010) \\
Electrona carlsbergi & $-22.6 \pm 0.5$ & $7.6 \pm 0.3$ & Polito \& Goebel (2010) \\
\hline
\end{tabular}

tors that also specialize in krill in the wAP area, specifically the Antarctic fur seal Arctocephalus gazella (Polito \& Goebel 2010) and the Adélie pen- guin Pygoscelis adeliae (Polito et al. 2011). We used non-informative priors in the mixing model due to the limitations associated with the small number of earlier studies, differences among studies in methodologies and reporting of results, and an overall lack of knowledge about the contribution of different fish species to the diet.

We used vibrissae-specific isotopic fractionation values of $2.2 \pm 0.7 \%$ o for $\delta^{13} \mathrm{C}$ and $3.5 \pm 0.6 \%$ for $\delta^{15} \mathrm{~N}$ in the mixing model, as obtained from a study of the sea otter Enhydra lutris (Newsome et al. 2010a), since studies reporting the discrimination of carbon and nitrogen isotopes between diet and vibrissae for pinnipeds have not reported standard deviations (Hobson et al. 1996, Kurle \& Worthy 2002, Lesage et al. 2002, Zhao et al. 2006). These values from Newsome et al. (2010a) are well within the range of mean enrichment factors estimated for pinniped vibrissae.

Our approach allowed us to sample different time periods in the foraging history of the seals, and consequently captured the variability in individual diets of crabeater seals. Assuming a growth rate similar to what has been described for the leopard seal Hydrurga leptonyx of $0.01 \mathrm{~mm} \mathrm{~d}^{-1}$ (Hall-Aspland et al. 2005) would imply that vibrissae samples in this study represented an average record of $1170 \mathrm{~d}$ (3.2 yr), which seems unlikely given the vibrissae growth pattern of phocids, which do not seem to retain vibrissae between years (Hirons et al. 2001b, Greaves et al. 2004, Newland et al. 2011, Hückstädt et al. 2012). New evidence from southern elephant seals Mirounga leonina suggests that at least part of the vibrissae is produced during the last weeks or few months (Newland et al. 2011). Yet, there is no certainty about the vibrissae growth rates for crabeater seals, and there are several unknowns about the pattern of vibrissae growth and shedding in phocids (Greaves et al. 
2004). Therefore, we did not assign specific timeframes for the different samples along the vibrissae, but rather treated them as relative terms of recent and past diet, and assumed that the isotopic information from vibrissae reflected the diet of the individual during the year preceding collection.

To assess the variability in the diet of crabeater seals at different levels, we ran MixSIR as follows: Approach 1, using mean individual isotopic values to address the diet of crabeater seals at the population level; Approach 2, using mean individual isotopic values separated by year, allowing us to investigate the difference in diet composition among sampling years; Approach 3, using all serial samples for each individual, providing us information on individual variability in diet composition; and Approach 4, using each vibrissa sample per individual to assess the temporal variability in diet composition of each individual. Results for the posterior distributions of prey item contribution to the diet, as obtained from the output of the MixSIR model, are expressed as median (with range).

We investigated the effect of year, season, sex and body mass on the contribution of krill (\%) to the diet of crabeater seals using a series of binomial generalized linear mixed effect models (GLMMs) with a 'logit' link function and the variable 'individual' as a random effect, using the package 'Ime4' in $\mathrm{R}$ (Bates et al. 2011). For these analyses, we used a subset of 10000 randomly selected samples obtained from each individual's posterior distributions as obtained from the MixSIR model. As before, the optimal model was chosen using the likelihood ratio test (Zuur et al. 2009).

All statistical analyses were conducted in R (R Development Core Team 2011). Results are expressed as mean values \pm SD unless otherwise noted, and the significance level was set at $95 \%$ for all tests.

\section{RESULTS}

We measured $\delta^{13} \mathrm{C}$ and $\delta^{15} \mathrm{~N}$ values in 389 samples obtained from 53 crabeater seals captured along the wAP (Table 2). The mean vibrissae length of our sample was $11.7 \pm 1.8 \mathrm{~cm}$, and we analyzed an average of $7.3 \pm 3.3$ segments per individual seal. Our samples were from 31 females and 22 males, with a mean mass of $256 \pm 54 \mathrm{~kg}$. The mean C:N atomic ratio for the vibrissae samples was $3.4 \pm 0.1$ (Table 2). Crabeater seals' individual $\delta^{13} \mathrm{C}$ and $\delta^{15} \mathrm{~N}$ values were significantly positively correlated (Pearson correlation, $\mathrm{R}=0.53, \mathrm{p} \ll 0.001$ ).
Table 2. Lobodon carcinophaga. Mean $( \pm \mathrm{SD}) \delta^{13} \mathrm{C}, \delta^{15} \mathrm{~N}$ (both $\%$ ) and C:N atomic ratio of 53 crabeater seals from the western Antarctic Peninsula, captured in 2001, 2002 and 2007, along with their ID, sex, and mass (kg). na: data not available

\begin{tabular}{|c|c|c|c|c|c|}
\hline ID & Sex & Mass & $\delta^{13} \mathrm{C}$ & $\delta^{15} \mathrm{~N}$ & $C: N$ \\
\hline \multicolumn{6}{|l|}{2001} \\
\hline \multicolumn{6}{|l|}{ Fall } \\
\hline G001 & Female & na & $-19.8 \pm 1.5$ & $7.1 \pm 0.1$ & $3.4 \pm 0.5$ \\
\hline G003 & Female & 258 & $-22.1 \pm 0.1$ & $5.3 \pm 0.7$ & $3.5 \pm 0.2$ \\
\hline G004 & Male & 342 & $-21.8 \pm 0.5$ & $6.7 \pm 0.7$ & $3.5 \pm 0.1$ \\
\hline G005 & Female & 293 & $-21.9 \pm 0.3$ & $6.6 \pm 0.5$ & $3.5 \pm 0.1$ \\
\hline G006 & Female & 413 & $-24.1 \pm 0.5$ & $6.2 \pm 0.4$ & $3.5 \pm 0.1$ \\
\hline G007 & Male & 287 & $-21.8 \pm 0.8$ & $6.4 \pm 0.5$ & $3.4 \pm 0.1$ \\
\hline G008 & Female & 355 & $-22.0 \pm 0.3$ & $6.8 \pm 0.4$ & $3.4 \pm 0.1$ \\
\hline \multicolumn{6}{|l|}{ Winter } \\
\hline G009 & Male & 179 & $-23.4 \pm 0.7$ & $6.2 \pm 0.3$ & $3.4 \pm 0.1$ \\
\hline G010 & Female & 307 & $-22.5 \pm 0.7$ & $6.5 \pm 0.4$ & $3.4 \pm 0.0$ \\
\hline G012 & Female & 288 & $-21.5 \pm 0.3$ & $6.8 \pm 0.7$ & $3.5 \pm 0.0$ \\
\hline G013 & Male & 234 & $-21.3 \pm 0.9$ & $6.7 \pm 0.5$ & $3.5 \pm 0.1$ \\
\hline G014 & Male & 284 & $-21.6 \pm 0.2$ & $7.6 \pm 0.7$ & $3.4 \pm 0.0$ \\
\hline G015 & Male & 234 & $-22.4 \pm 0.3$ & $7.3 \pm 0.7$ & $3.5 \pm 0.1$ \\
\hline G016 & Female & 273 & $-21.1 \pm 0.2$ & $5.9 \pm 0.4$ & $3.5 \pm 0.1$ \\
\hline \multicolumn{6}{|l|}{2002} \\
\hline \multicolumn{6}{|l|}{ Fall } \\
\hline G017 & Female & 118 & $-21.8 \pm 0.4$ & $6.8 \pm 1.3$ & $3.3 \pm 0.1$ \\
\hline G018 & Male & 157 & $-24.9 \pm 0.7$ & $6.5 \pm 0.6$ & $3.3 \pm 0.1$ \\
\hline G019 & Female & 156 & $-24.7 \pm 0.6$ & $6.6 \pm 0.7$ & $3.3 \pm 0.0$ \\
\hline G020 & Male & 143 & $-24.5 \pm 0.7$ & $6.6 \pm 0.7$ & $3.3 \pm 0.1$ \\
\hline G021 & Male & 271 & $-22.3 \pm 0.7$ & $6.7 \pm 0.6$ & $3.4 \pm 0.1$ \\
\hline G022 & Female & 268 & $-20.9 \pm 0.3$ & $7.9 \pm 0.5$ & $3.4 \pm 0.1$ \\
\hline G023 & Male & 174 & $-24.6 \pm 0.6$ & $6.4 \pm 0.6$ & $3.3 \pm 0.1$ \\
\hline G024 & Female & 256 & $-21.8 \pm 0.9$ & $7.2 \pm 0.5$ & $3.3 \pm 0.1$ \\
\hline G026 & Female & 266 & $-23.6 \pm 0.2$ & $6.5 \pm 0.5$ & $3.3 \pm 0.1$ \\
\hline G027 & Male & 226 & $-22.3 \pm 0.8$ & $6.9 \pm 0.5$ & $3.3 \pm 0.0$ \\
\hline G028 & Female & 314 & $-22.2 \pm 1.1$ & $7.1 \pm 0.9$ & $3.3 \pm 0.1$ \\
\hline G029 & Male & 242 & $-21.6 \pm 1.0$ & $7.2 \pm 0.9$ & $3.3 \pm 0.0$ \\
\hline G030 & Male & 250 & $-22.1 \pm 1.0$ & $6.9 \pm 1.1$ & $3.3 \pm 0.0$ \\
\hline G031 & Female & 385 & $-21.2 \pm 0.6$ & $7.5 \pm 0.6$ & $3.3 \pm 0.0$ \\
\hline G032 & Female & 230 & $-23.2 \pm 0.7$ & $7.0 \pm 0.5$ & $3.3 \pm 0.0$ \\
\hline \multicolumn{6}{|l|}{ Winter } \\
\hline G033 & Female & 268 & $-21.1 \pm 0.9$ & $7.5 \pm 0.9$ & $3.3 \pm 0.1$ \\
\hline G034 & Female & 295 & $-21.8 \pm 0.6$ & $6.7 \pm 0.4$ & $3.3 \pm 0.1$ \\
\hline G035 & Female & 238 & $-21.6 \pm 0.5$ & $7.0 \pm 0.6$ & $3.3 \pm 0.0$ \\
\hline G036 & Female & 207 & $-21.5 \pm 1.0$ & $7.3 \pm 0.4$ & $3.4 \pm 0.1$ \\
\hline G038 & Male & 273 & $-22.0 \pm 1.2$ & $6.9 \pm 0.5$ & $3.4 \pm 0.1$ \\
\hline G039 & Male & 247 & $-22.9 \pm 0.4$ & $7.3 \pm 0.6$ & $3.4 \pm 0.1$ \\
\hline G040 & Male & 302 & $-23.7 \pm 0.6$ & $6.5 \pm 0.5$ & $3.4 \pm 0.1$ \\
\hline G041 & Male & 269 & $-22.9 \pm 0.5$ & $6.7 \pm 0.5$ & $3.4 \pm 0.1$ \\
\hline G042 & Male & 224 & $-21.6 \pm 1.2$ & $6.9 \pm 0.5$ & $3.5 \pm 0.1$ \\
\hline G043 & Male & 224 & $-22.8 \pm 0.8$ & $7.4 \pm 0.5$ & $3.4 \pm 0.1$ \\
\hline G044 & Female & 280 & $-21.8 \pm 1.2$ & $7.1 \pm 0.8$ & $3.5 \pm 0.1$ \\
\hline G045 & Female & 221 & $-22.0 \pm 0.3$ & $7.6 \pm 0.7$ & $3.4 \pm 0.1$ \\
\hline G046 & Male & 237 & $-21.7 \pm 0.9$ & $7.8 \pm 0.6$ & $3.4 \pm 0.0$ \\
\hline G047 & Male & 254 & $-21.5 \pm 1.2$ & $7.1 \pm 0.5$ & $3.5 \pm 0.1$ \\
\hline \multicolumn{6}{|l|}{2007} \\
\hline \multicolumn{6}{|l|}{ Fall } \\
\hline G102 & Female & 286 & $-23.8 \pm 0.5$ & $5.3 \pm 0.3$ & na \\
\hline G104 & Female & 197 & $-22.7 \pm 0.7$ & $6.9 \pm 0.3$ & $3.4 \pm 0.1$ \\
\hline G105 & Female & 251 & $-22.3 \pm 1.2$ & $7.1 \pm 0.5$ & na \\
\hline G106 & Female & 207 & $-21.9 \pm 0.7$ & $7.1 \pm 0.2$ & $3.5 \pm 0.0$ \\
\hline G107 & Female & 315 & $-23.3 \pm 1.1$ & $6.6 \pm 0.2$ & na \\
\hline G108 & Female & 207 & $-21.5 \pm 1.6$ & $7.5 \pm 0.5$ & $3.4 \pm 0.1$ \\
\hline G110 & Female & 123 & $-23.1 \pm 0.2$ & $7.9 \pm 1.0$ & na \\
\hline G112 & Female & 252 & $-24.0 \pm 0.5$ & $5.4 \pm 0.7$ & $3.4 \pm 0.0$ \\
\hline G113 & Female & 244 & $-23.3 \pm 0.5$ & $5.8 \pm 0.4$ & $3.5 \pm 0.0$ \\
\hline G114 & Male & 304 & $-22.3 \pm 1.2$ & $7.1 \pm 0.4$ & na \\
\hline
\end{tabular}




\section{Vibrissae $\delta^{13} \mathrm{C}$ values}

The mean $\delta^{13} \mathrm{C}$ value for all 389 samples was $-22.4 \pm 1.3 \%$. There was considerable variability in mean $\delta^{13} \mathrm{C}$ values for individuals, which ranged from $-24.9 \%$ for seal G018 to $-19.8 \%$ for seal G001 (Table 2); the $\delta^{13} \mathrm{C}$ SD for individuals varied by an order of magnitude, from $0.1 \%$ for seal G003 to $1.5 \%$ for seal G001 (Table 2).

Before fitting the models for $\delta^{13} \mathrm{C}$ values, we transformed the data, as $\log _{10}\left(\delta^{13} \mathrm{C}+30\right)$, to fulfill the assumption of residual normality. In the optimal model, $\delta^{13} \mathrm{C}$ values of crabeater seal vibrissae were positively related to mass $(t=2.12, \mathrm{p}=0.04)$ and higher during the winter season compared with the fall $(t=2.37, \mathrm{p}=0.02)$. The results of MMVCA confirmed the importance of individual seals to the variability found in crabeater seal $\delta^{13} \mathrm{C}$ values, $59.6 \%$ of which is associated with individual variability, and approximately $40 \%$ is due to variability within individuals. Indeed, we could not identify common patterns among individuals with regards to the alongvibrissae variability in $\delta^{13} \mathrm{C}$ values (Fig. 2).

\section{Vibrissae $\delta^{15} \mathbf{N}$ values}

The mean $\delta^{15} \mathrm{~N}$ value for the 389 samples of crabeater seal vibrissae was $6.8 \pm 0.8 \%$, and the mean value for individuals varied from $5.3 \%$ (seal G003) to $7.9 \%$ (seal G022). Similar to $\delta^{13} \mathrm{C}$ results, the SD for different individuals ranged from $0.1 \%$ (seal G001) to $1.3 \%$ (seal G017) (Table 2).

Since our data did not fulfill the assumption of homogeneity of variance for the variable year, our suite of models for $\delta^{15} \mathrm{~N}$ values included a variance structure (VarIdent), allowing each year to have different variance in the models. The optimal model included only the effect of the year in the $\delta^{15} \mathrm{~N}$ values (individuals in 2002 had higher $\delta^{15} \mathrm{~N}$ values, $t=2.52$, $\mathrm{p}=0.02$ ). The variance in $\delta^{15} \mathrm{~N}$ values was, however, evenly split between the individual $(49.3 \%)$ and the within-individual $(50.7 \%)$ components, according to the MMVCA, and, as with $\delta^{13} \mathrm{C}$, no common patterns were identified among individuals in the vibrissae variability in $\delta^{15} \mathrm{~N}$ values (Fig. 2).

\section{Diet composition: population versus individuals}

The high carbon values for seal G001 (Table 2) indicate that this individual foraged north of the Polar Front/Sub-Polar Front (see 'Discussion: Sub-
Antarctic foraging'), so it was not included in the analysis.

A limitation of using stable isotopes for diet analysis is that it is not possible to reconstruct the diet without knowledge of the isotopic composition of potential or actual prey items for a consumer (Kelly 2000, Newsome et al. 2010b). Furthermore, isotopic mixing models cannot differentiate between the contributions of different prey unless prey isotopic values are significantly different (Phillips 2001, Phillips et al. 2005, Moore \& Semmens 2008). While we included 3 fish species in our mixing models (Table 3 ), Pleurogramma antarcticum and Electrona antarctica have very similar $\delta^{13} \mathrm{C}$ values $(-24.7 \pm 0.4 \%$ and $-25.1 \pm 0.9 \%$, respectively) and identical $\delta^{15} \mathrm{~N}$ values (9.4 $\pm 0.5 \%$ and $9.4 \pm 0.6 \%$, respectively) (Polito \& Goebel 2010, Polito et al. 2011), preventing us from distinguishing the contribution of each species to the diet. We therefore pooled the results for all 3 fish species by adding their posterior distributions in all further analyses.

Our analysis demonstrated that Antarctic krill were the predominant prey taxa in the diet of crabeater seals from the wAP (Approach 1). Krill accounted for $87.9 \%(81.2-94.8 \%)$ of the diet of the crabeater seals, whereas the cumulative contribution of all 3 species of fish was $12.1 \%(5.2-18.8 \%)$ of their diet (Table 3). There was a decrease in the contribution of krill to crabeater seal diet in 2002, compared with 2001 and 2007 (Approach 2; Table 3, Fig. 3). This was confirmed by the GLMM, which identified year (2002) as the only significant variable $(z=-2.0, \mathrm{p}=0.04)$.

As expected, and in agreement with the results obtained from the MMVCA, we observed a high degree of variability in the diet of individual seals (Fig. 4). The median contribution of krill varied among individual seals (Approach 3), from 60.8\% (40.6-80.7\%, seal G022) to $98.3 \%(92.5-99.9 \%$, seal G102). At the individual level there was an increase in the uncertainty of the model results, with the contribution of krill to diet ranging by as much as $67 \%$ in the diet of particular individuals (i.e. seal G024, Fig. 4).

\section{Temporal variability in the diet}

We were able to identify temporal differences in the diet of seals (as obtained from the longitudinal record of isotopic values along the vibrissae, Approach 4 ; Fig. 5). Whereas most individuals showed low variability in the median contribution of krill to their diets (Fig. 5), some individual diets fluctuated through time. In 20 seals $(38.5 \%$ of sampled individ- 


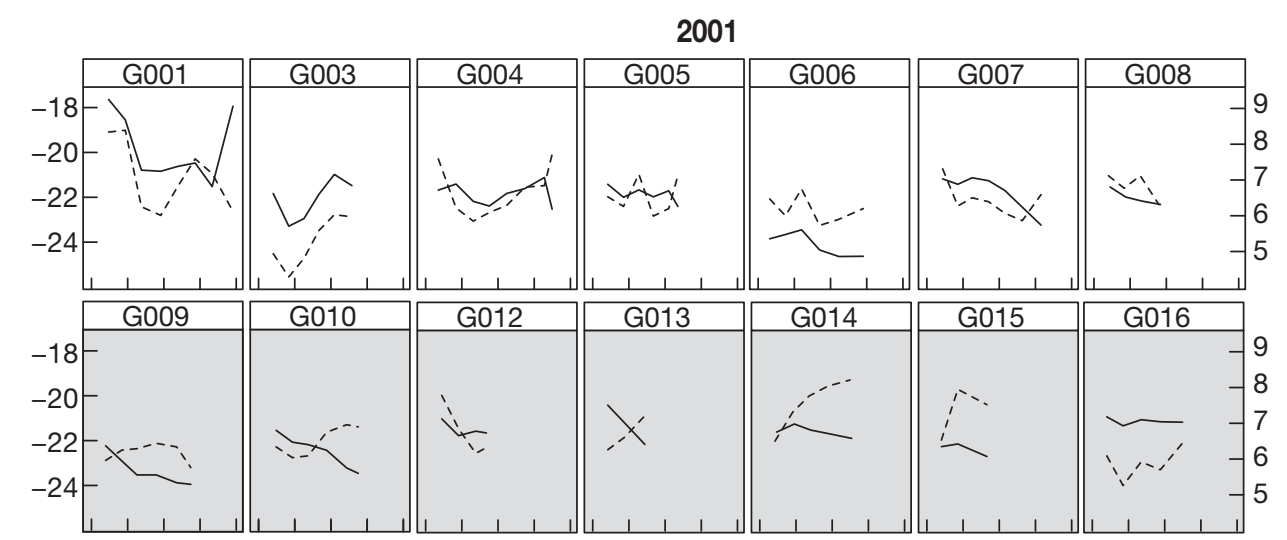

2002
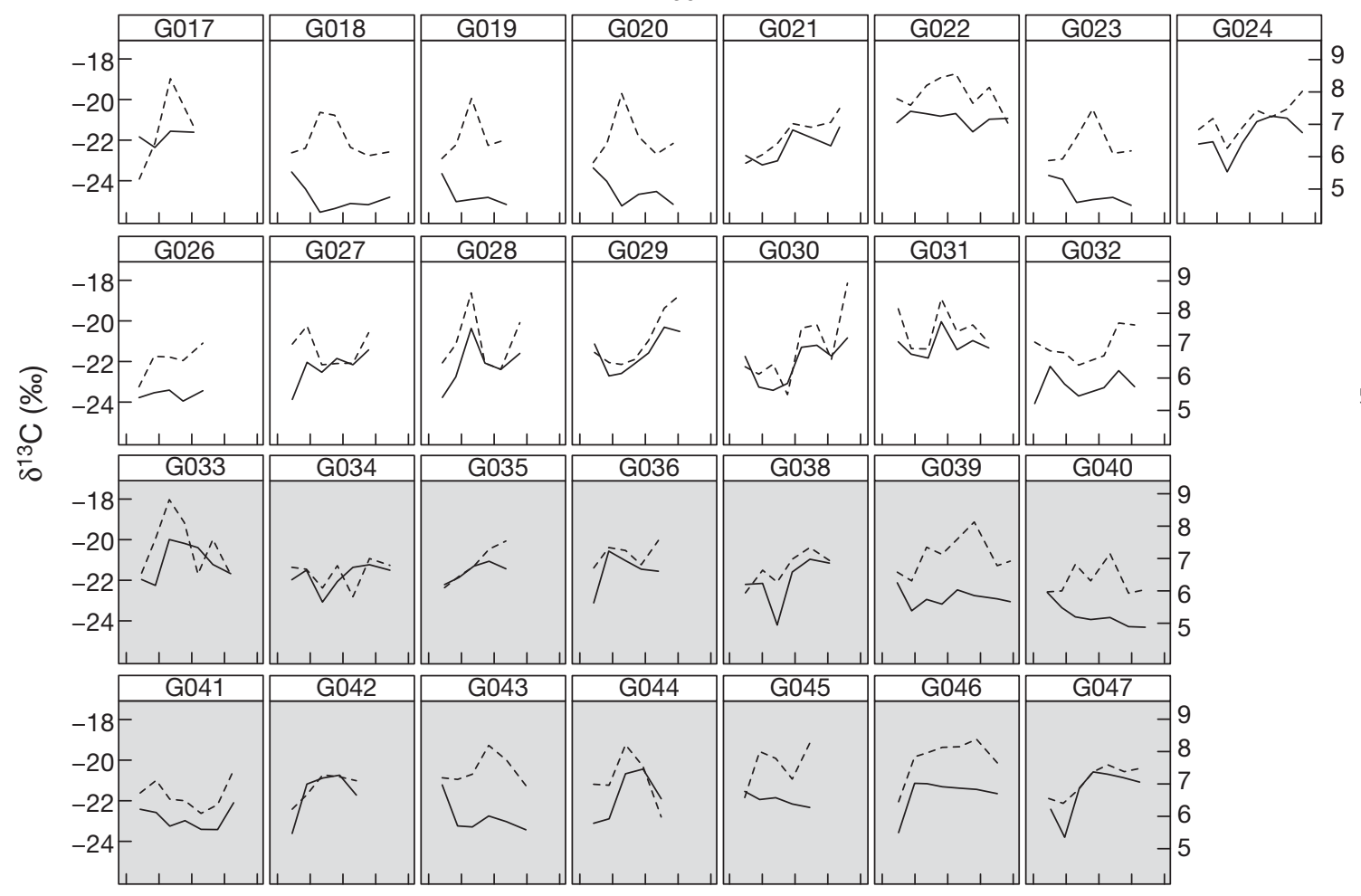

2007

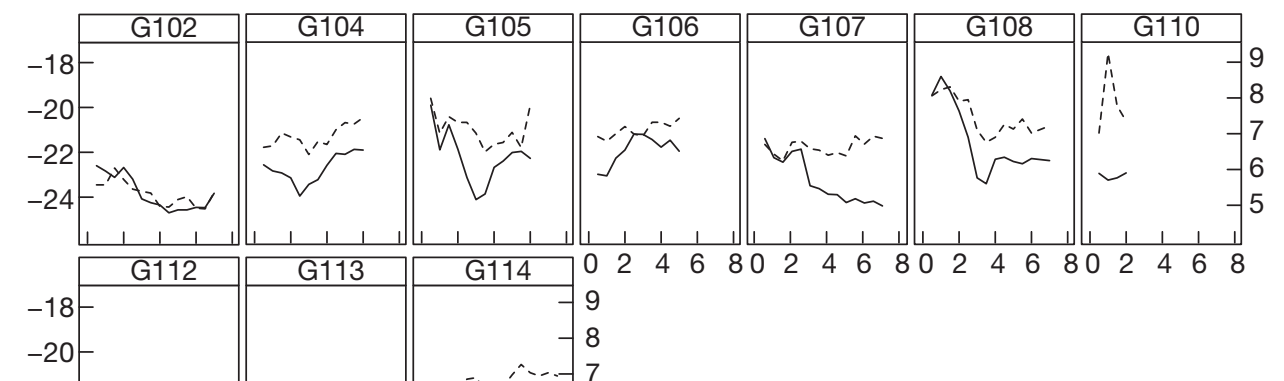

Fig. 2. Lobodon carcinophaga. Variation of $\delta^{13} \mathrm{C}$ (solid line) and $\delta^{15} \mathrm{~N}$ (dashed line) along vibrissae of crabeater seals captured along the western Antarctic Peninsula in 2001, 2002 and 2007. White panels: fall captures; gray panels: winter captures 
Table 3. Contribution of fish and krill (\%) to the diet of crabeater seals Lobodon carcinophaga from the western Antarctic Peninsula, taking into account individual mean $\delta^{13} \mathrm{C}$ and $\delta^{15} \mathrm{~N}$ values. Values represent median (with range) of the posterior distributions obtained for each prey item included in the diet, as obtained from the Bayesian mixing model MixSIR v1.0 (Moore \& Semmens 2008, Semmens \& Moore 2008)

\begin{tabular}{|c|c|c|c|c|c|}
\hline & & - Fish & 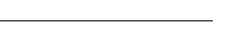 & \multirow{2}{*}{ Total fish (\%) } & \multirow{2}{*}{ Krill (\%) } \\
\hline & $\begin{array}{c}\text { Pleuragramma } \\
\text { antarcticum (\%) }\end{array}$ & $\begin{array}{c}\text { Electrona } \\
\text { antarctica (\%) }\end{array}$ & $\begin{array}{c}\text { Electrona } \\
\text { carlsbergi }(\%)\end{array}$ & & \\
\hline 2001 & $0.8(0-8.3)$ & $0.8(0-9.0)$ & $5.9(0.01-20.7)$ & $8.4(0.9-21.4)$ & $91.6(78.6-99.1)$ \\
\hline 2002 & $0.6(0-5.9)$ & $0.6(0-6.2)$ & $14.0(3.6-24.7)$ & $15.5(7.6-24.9)$ & $84.5(75.1-92.4)$ \\
\hline 2007 & $1.5(0-16.9)$ & $1.4(0-13.1)$ & $4.2(0-20.5)$ & $8.9(0.4-22.0)$ & $91.1(78.0-99.6)$ \\
\hline All data & $0.4(0-5.4)$ & $0.3(0-3.4)$ & $11.2(3.5-18.3)$ & $12.1(5.2-18.8)$ & $87.9(81.2-94.8)$ \\
\hline
\end{tabular}

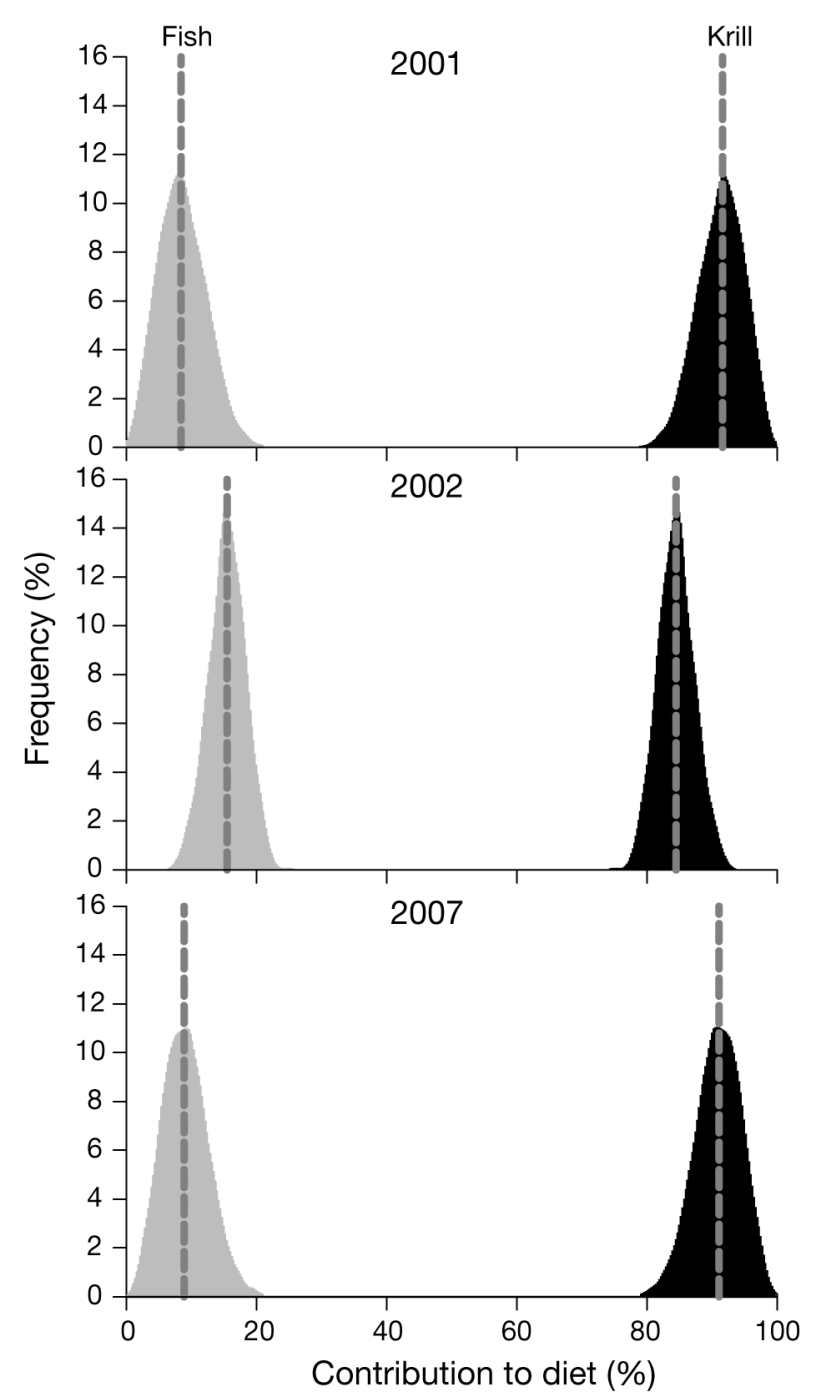

Fig. 3. Lobodon carcinophaga. Contribution of prey items to the diet of crabeater seals from the western Antarctic by year (2001, 2002 and 2007). Prey contribution to the diet was calculated based on vibrissae $\delta^{13} \mathrm{C}$ and $\delta^{15} \mathrm{~N}$ values, using the Bayesian mixing model MixSIR. Black: Antarctic krill Euphausia superba; gray: fish species Pleuragramma antarcticum, Electrona antarctica and E. carlsbergi (combined); dashed line: median
Fish Krill

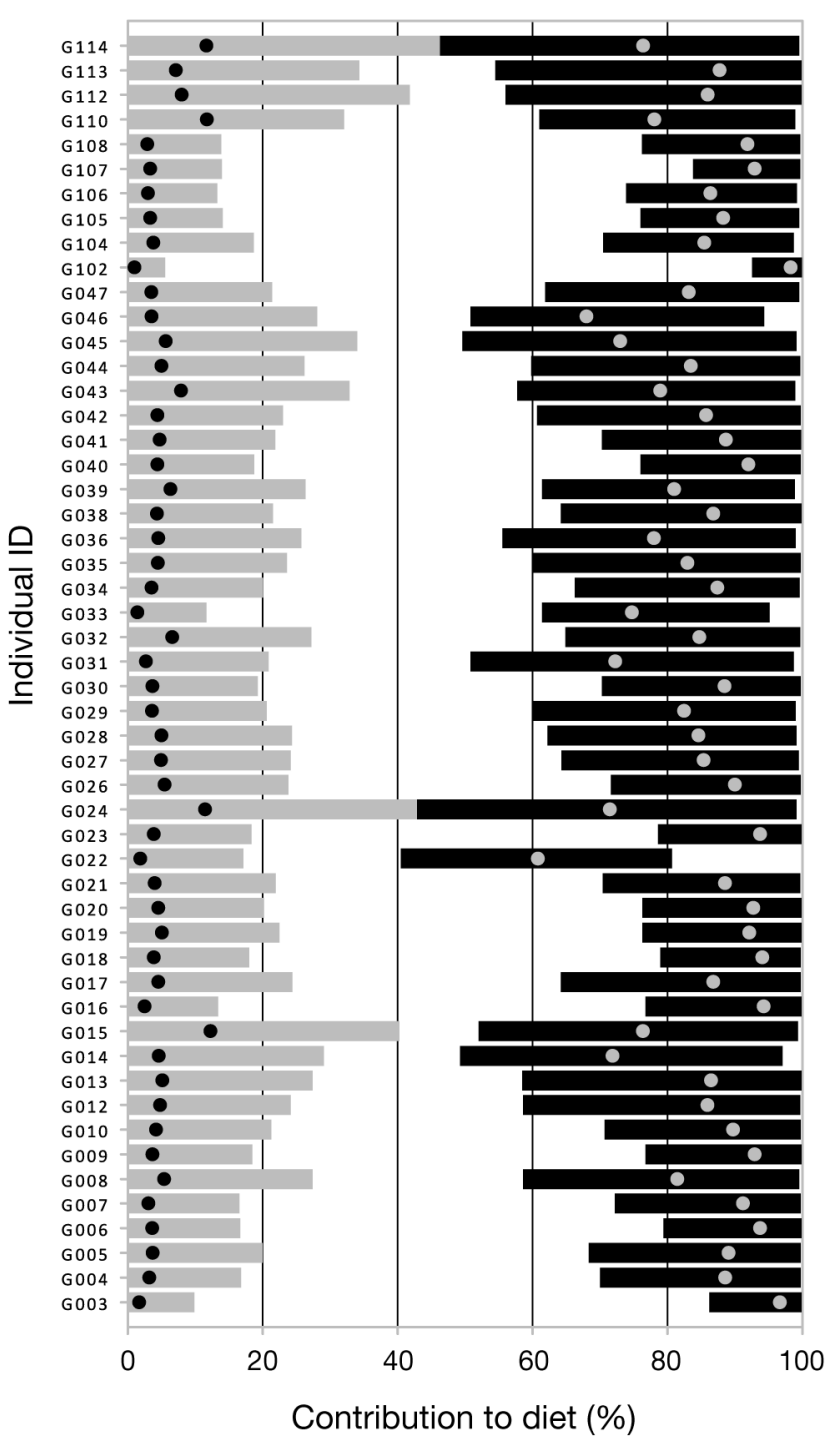

Fig. 4. Lobodon Carcinophaga. Individual variation in the contribution of Antarctic krill Euphausia superba and fish (3 species combined; see Table 1) to diet of crabeater seals from the western Antarctic Peninsula. Bars: range; dots: median 

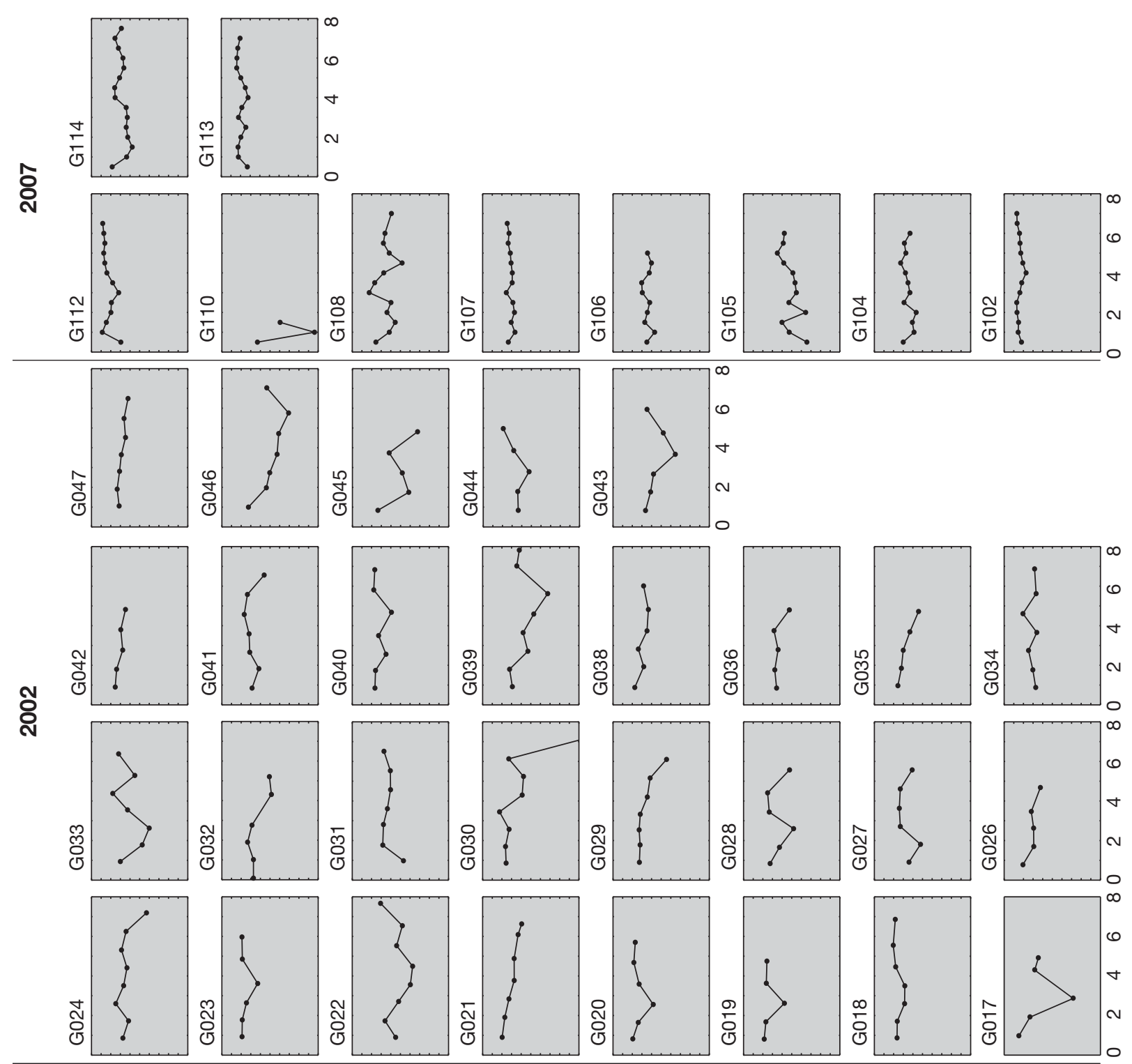

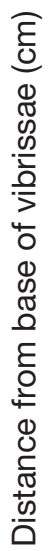
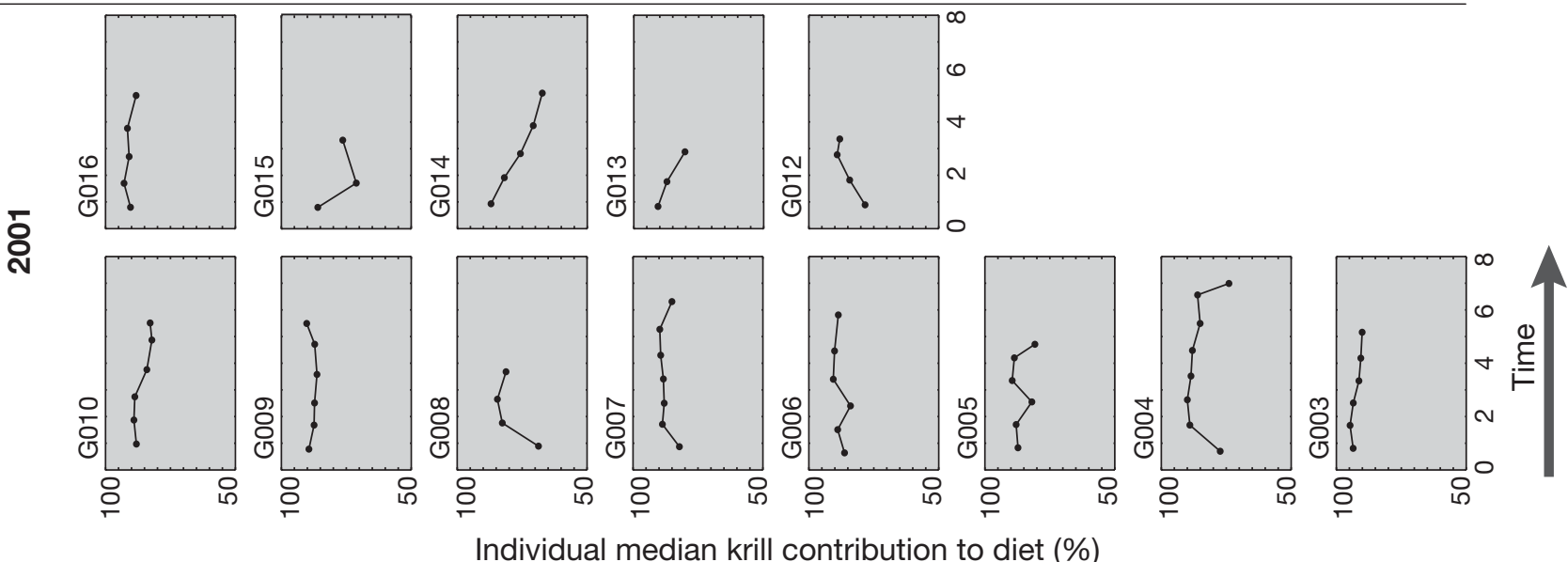

Fig. 5. Lobodon carcinophaga. Temporal variation in the median contribution (\%) of Antarctic krill Euphausia superba to the diet of individual crabeater seals from the western Antarctic Peninsula. Vibrissae samples provide a continuum in the diet history of the individual, from the proximal sample (closer to the base) representing the most recent diet information, to the distal sample (farther away from the base) providing the oldest diet information. Individual IDs are provided in the top left corner of each panel 
uals), the median krill contribution to the diet dropped below $75 \%$ of the diet at least once in the time period recorded in the vibrissae, in some cases dropping as low as 48.6\% (seal G030, Fig. 5).

\section{DISCUSSION}

This is the first study using stable isotopes to examine the diet composition of crabeater seals in the wAP. We evaluated dietary information assimilated over a timescale of, at least, months based on the analysis of a slow-growing tissue (i.e. vibrissae), rather than the instantaneous snapshot from scats, or stomach content analysis (Kelly 2000, Crawford et al. 2008). Our data demonstrated the predominance of krill in the diet of crabeater seals from the wAP ( $\sim 88 \%$ of their diet), in agreement with previous studies (Laws 1977, Green \& Williams 1986, Lowry et al. 1988, Hewitt \& Lipsky 2009). We also showed individual and temporal variability in the contribution of krill to the diet of crabeater seals, highlighting the importance of understanding the responses of this highly specialized predator to the environmental variability of its prey, especially in light of the rapid and drastic environmental changes in the study area (Atkinson et al. 2004, Stammerjohn et al. 2008).

\section{$\delta^{13} \mathrm{C}$ and $\delta^{15} \mathrm{~N}$ values}

Despite the importance of crabeater seals as one of the major consumers of Antarctic krill in the Southern Ocean (Laws 1977, Hill et al. 2006, Hewitt \& Lipsky 2009), there are relatively few studies on the trophic ecology of this predator, and most have been based on stomach content and scat analysis. To our knowledge, only 2 studies have measured isotopic values of crabeater seals (Rau et al. 1992, Zhao et al. 2004) from blood or muscle samples. These tissues integrate dietary information on a scale of days (blood serum) to months (muscle; Hobson et al. 1996, Dalerum \& Angerbjorn 2005, Kurle \& Gudmundson 2007), but these samples do not provide a way to address temporal variability of an individual's diet if samples are taken at one particular time only, as in the case of these studies where either serum or muscle samples were collected from particular individuals. However, if the variability in $\delta^{13} \mathrm{C}$ and/or $\delta^{15} \mathrm{~N}$ values is quantified between different tissue samples (e.g. muscle and blood serum) collected from the same individual at the same time, individual and temporal variability in the diets of individuals, as detected by stable isotope analysis, can be investigated due to differences in the reflection of an individual's diet attributed to differences in the turnover rate of different body tissues (e.g. Bearhop et al. 2004, Quevedo et al. 2009, Matich et al. 2011).

Crabeater seals from the wAP showed greater variability in both $\delta^{13} \mathrm{C}$ and $\delta^{15} \mathrm{~N}$ values than that found by Rau et al. (1992) in the Weddell Sea and by Zhao et al. (2004) in the Ross Sea (both in the Southern Ocean). For instance, Rau et al. (1992) reported $\delta^{13} \mathrm{C}$ values for muscle that varied by about $4 \%$ among individuals, whereas Zhao et al. (2004) reported individual values that varied by $3.7 \%$ for lipid-extracted blood serum. Individual mean $\delta^{13} \mathrm{C}$ values showed greater variability in our study $(4.8 \%$, Table 1$)$. Yet we also found an important contribution from the within-individual variability in $\delta^{13} \mathrm{C}$ values, which explained about $40 \%$ of the variance of the isotope. Thus, when considering all samples in this study, the variability of crabeater seal $\delta^{13} \mathrm{C}$ values increased to $7.9 \%$. Similarly, mean individual $\delta^{15} \mathrm{~N}$ values varied by $2.7 \%$, whereas all samples varied by $5 \%$, compared to $\sim 1.2 \%$ in the Weddell Sea (Rau et al. 1992), and $\sim 2.3 \%$ in the Ross Sea (Zhao et al. 2004).

Several factors might contribute to the differences in variance between our study and the previously published studies of crabeater seals. First, measuring isotopic values along a metabolically inert tissue, such as vibrissae, provides a continuous and timeintegrated record of the seal's foraging ecology, sampled at relatively high resolution (Hall-Aspland et al. 2005, Newsome et al. 2009, Eder et al. 2010, Newland et al. 2011). Regardless of the time period integrated in 1 sample of serum (days) or muscle (months), these tissues only provide 1 data point in time unless a longitudinal study of the same individual can be conducted, which is not realistic in the case of the wild animals used in our sample. One vibrissa, on the other hand, offers a stratified record in time, therefore providing several samples for the same individual, as opposed to the unique value that 1 muscle or serum sample can provide.

Second, isotope values at the base of trophic webs vary regionally, due to differences in oceanographic parameters such as temperature, productivity, physiology and identity of primary producers, vertical mixing, and isotopic differences in the main sources of carbon and nitrogen (Somes et al. 2010). At a global scale, $\delta^{13} \mathrm{C}$ decreases towards the poles and because this isotopic gradient is more pronounced in the Southern Ocean (Goericke \& Fry 1994, Popp et al. 1999, Graham et al. 2009), the North-South orientation of the wAP, spanning $12^{\circ}$ in latitude, is of partic- 
ular relevance when comparing isotopic variability. This is ultimately reflected throughout the trophic web around the wAP, which could explain the high range of $\delta^{13} \mathrm{C}$ values we see in our data compared to other sites. $\delta^{15} \mathrm{~N}$ values also decrease towards the poles (Jaeger et al. 2010a, Somes et al. 2010), although this relationship is harder to evaluate in consumers as variations in $\delta^{15} \mathrm{~N}$ values are also associated with changes in trophic level.

Third, Zhao et al. (2004) suggested that the gradient in $\delta^{13} \mathrm{C}$ values between onshore and offshore waters contributed to the wide range of $\delta^{13} \mathrm{C}$ values they observed in crabeater seals from the Ross Sea. Tracking data show, however, that along the wAP crabeater seals are restricted to shelf waters (Burns et al. 2004, 2008, Costa et al. 2008, 2010), consequently an onshore-offshore $\delta^{13} \mathrm{C}$ gradient is unlikely to contribute to the isotopic variability we observed.

Despite these possible explanations, we propose that the high variation in crabeater seals' isotopic values is likely associated with the high variability of isotopic values at the base of the food web. The isotopic composition of krill varies as they switch between grazing on pelagic and sea ice diatoms, the latter of which are typically enriched in ${ }^{13} \mathrm{C}$ and ${ }^{15} \mathrm{~N}$ (Wada et al. 1987). These isotopic differences are integrated by krill and other phytoplankton consumers (Schmidt et al. 2003), and are then transferred up through the food web to crabeater seals. These changes in baseline isotopic values, a consequence of the shift between a pelagic and sea ice phytoplankton community, could also explain the significant effect that season had on $\delta^{13} \mathrm{C}$ values of crabeater seals. Finally, despite being a highly specialized predator, crabeater seals do consume prey other than krill (Laws 1977, Green \& Williams 1986, Lowry et al. 1988, Hewitt \& Lipsky 2009), and therefore we can expect changes in their isotopic values as they incorporate more than one prey in their diet (see 'Diet of crabeater seals' section below).

\section{Sub-Antarctic foraging}

Based on the relationship between latitude and $\delta^{13} \mathrm{C}$ values, it is possible to identify oceanographic features utilized by top predators in the Southern Ocean, such as the Polar Front, with $\delta^{13} \mathrm{C}$ values measured in penguin and fur seal blood of -22.9 to $-22.5 \%$, and the Sub-Polar Front, with $\delta^{13} \mathrm{C}$ values of -20.1 to $-19.7 \%$ in the same type of samples (Cherel \& Hobson 2007, Jaeger et al. 2010b). Crabeater seals have rarely been observed in sub-Antarctic latitudes, and most reports refer to juvenile or injured animals (Knox 2007, Bengtson 2009). However, 1 individual in our study, G001, had $\delta^{13} \mathrm{C}$ values that ranged between -21.5 and $-17.6 \%$ (Table 2, Fig. 2), which indicates that this individual foraged north of the Sub-Polar Front. The maximum $\delta^{13} \mathrm{C}$ value for this individual $(-17.6 \%)$ is higher than vibrissae $\delta^{13} \mathrm{C}$ values of female southern elephant seals Mirounga leonina from the wAP (Hückstädt et al. 2012), which reportedly feed as far north as the Sub-Polar Front (Costa et al. 2010, Hückstädt et al. 2012), and was within the range of $\delta^{13} \mathrm{C}$ values reported for other species that forage north of the Polar Front, such as rockhopper penguins Eudyptes chrysocome (Cherel et al. 2007), macaroni penguins E. chrysolophus, Antarctic fur seals Arctocephalus gazella (Cherel \& Hobson 2007), and Wilson's storm petrel Oceanites oceanicus (Quillfeldt et al. 2005).

A closer look at $\delta^{13} \mathrm{C}$ values along the vibrissae profile (Fig. 2), provides evidence of individual G001 transiting back and forth between an area north of the Polar Front and the Antarctic continental margin, as observed from the 2 peaks in $\delta^{13} \mathrm{C}$ (north foraging), and the low values (Antarctic foraging). A final transit to the Antarctic continent (not seen in the vibrissae isotopic data) is evident since the individual was captured along the wAP. Thus, this constitutes the first record of a crabeater seal successfully transiting between sub-Antarctic and Antarctic foraging grounds.

\section{Diet of crabeater seals}

Although most studies on diet of crabeater seals have distinguished between krill and unspecified fish species, we included 3 different species of fish that occur in the diet of other krill specialists in the same study area (Polito \& Goebel 2010, Polito et al. 2011, our Table 3 ). However, due to the similarity in isotopic values for 2 of the fish species included in our analysis, we combined the diet contributions obtained from the mixing model for all 3 species of fish (Table 3, Fig. 3). Our results show that the diet of the crabeater seal along the wAP is largely dominated by krill, which accounts for $88 \%$ of the diet when considering individual isotopic mean values (Approach 1). Our results for fish species, however, are more difficult to interpret.

Our data show that crabeater seals display some trophic plasticity, likely a response to fluctuations in the availability of their primary prey, Antarctic krill. Large fluctuations in the biomass of Antarctic krill in 
the wAP have been described (Siegel \& Loeb 1995, Hewitt et al. 2003, Reiss et al. 2008) and linked to environmental variations at different scales, from local fluctuations in sea ice extent (Loeb et al. 1997), to global-scale perturbations such as El Niño Southern Oscillation (Loeb et al. 2009). Our study included samples collected during the austral fall and winter of 2002, presumably reflecting krill consumption during the austral summer 2001 to 2002. This particular summer season was characterized by one of the lowest recorded biomasses of krill for the northern wAP (Hewitt et al. 2003, Reiss et al. 2008). Our analysis revealed that the contribution of krill to the diet of crabeater seals was significantly lower in 2002 compared with 2001, whereas no difference was evident between 2001 and 2007 (Figs. 3 \& 4). Seals sampled in 2002 had the lowest median contribution of krill to diet, with about half of the individuals in our sample having median contributions to diet of less than $75 \%$ at least once along their vibrissae (Fig. 5). Fish are enriched in $\delta^{15} \mathrm{~N}$ compared to Antarctic krill (Cherel \& Hobson 2007, Cherel et al. 2007, Polito \& Goebel 2010, Polito et al. 2011), and this higher proportion of fish in the diet of the seals is not surprising considering that our results indicated that seals in 2002 had significantly higher $\delta^{15} \mathrm{~N}$ than in other years.

Seasonal fluctuations in biomass and vertical distribution of Antarctic krill have also been observed for the WAP, with less dense $\left(<10 \mathrm{~g} \mathrm{~m}^{-3}\right)$ and deeper aggregations during the fall-winter period compared with high density $\left(>100 \mathrm{~g} \mathrm{~m}^{-3}\right)$ and shallow aggregations observed in summer (Lascara et al. 1999). Regardless, crabeater seals are able to prey on krill throughout the fall-winter season, as the krill's vertical distribution remains well within the diving range of crabeater seals (Burns et al. 2004). Furthermore, deeper krill aggregations are likely to be denser, making up for the deeper and therefore longer dives that would be required to obtain them (Burns et al. 2004, 2008). Nonetheless, the variations observed in the median contribution of krill along vibrissae (Fig. 5) can be interpreted as a change in the diet of crabeater seals as they respond to changes in the availability of their prey (krill and fish).

Evidence from tagging studies of crabeater seals in the WAP indicates that their foraging behavior switches from shallow, short dives in summer, to deeper, longer dives in the winter, likely in response to changes in vertical distribution of their prey (Burns et al. 2004). Yet, they are capable of maintaining, or even increasing their body mass during winter (McDonald et al. 2008). Burns et al. (2004) suggested that, regardless of the crabeater seals' high level of specialization on a single prey, they display behavioral plasticity to forage successfully in winter, when there is lower availability of their main prey. Our study offers evidence that their plasticity is not only related to changes in patterns of habitat utilization and diving behavior as previously suggested (Burns et al. 2004), but also the inclusion of other prey (i.e. fish) in their diet. Similar findings have been described for Adélie penguins along the WAP, whose diet shifts from primarily krill in the summer breeding season to include $>50 \%$ fish during winter (Lynnes et al. 2004, Polito et al. 2011). It is unknown, however, to what extent and at what rate crabeater seals might be able to switch from a krill-dominated diet to a more generalized one, under the current scenario of rapid climate change that is occurring along the wAP (Costa et al. 2010).

Acknowledgements. We express our gratitude towards J. Barnes, B. Chittick, M. Fedak, A. Friedlander, N. Gales, M. Goebel, T. Goldstein, M. Gray, M. Hindell, C. Kuhn, P. Robinson, S. Shaffer, D. Shuman, S. Simmons, S. Trumble and S. Villegas-Amtmann for their help in the field. Logistic and scientific support was provided by SO GLOBEC, RV 'Lawrence M. Gould', Palmer Station (NSF) and Rothera Station (BAS). Thanks to D. Andreasen, B. Walker, J. Lehman and L. Roland for their assistance in the analysis of samples. M. Fowler and 4 anonymous reviewers made suggestions that greatly contributed to improve the manuscript. This research was supported by the National Science Foundation through the Office of Polar Programs (grants ANT0440687, 0840375, 0523332, and 0838937), National Undersea Research Program, National Oceanographic Partnership Program through the Office of Naval Research, and the Marine Mammal Commission. L.A.H. was supported by CONICYT-Fulbright (Chile). B.I.M. was supported by a NSF predoctoral fellowship and EPA STAR fellowship. All animal captures were authorized under National Marine Fisheries Service permits nos. 87-1593 and 87-1851-00, and approved by the Institutional Animal Care and Use Committee (IACUC) at University of California Santa Cruz, and the University of Alaska, Anchorage. This is US GLOBEC contribution no. 711.

\section{LITERATURE CITED}

Atkinson A, Siegel V, Pakhomov E, Rothery P (2004) Longterm decline in krill stock and increase in salps within the Southern Ocean. Nature 432:100-103

Bates D, Maechler M, Bolker B (2011) lme4: Linear mixedeffects models using S4 classes. R package version 0.999375-40. Available at http://cran.r-project.org/web/ packages/lme4/index.html

Bearhop S, Hilton GM, Votier SC, Waldron S (2004) Stable isotope ratios indicate that body condition in migrating passerines is influenced by winter habitat. Proc R Soc Lond B 271:S215-S218

Bengtson JL (2009) Crabeater seal Lobodon carcinophaga. In: Perrin WF, Wursig B, Thewissen JGM (eds) Encyclopedia of marine mammals. Academic Press, San Diego, CA, p 290-292 
Bowen WD (2000) Reconstruction of pinniped diets: accounting for complete digestion of otoliths and cephalopod beaks. Can J Fish Aquat Sci 57:898-905

Burns JM, Costa DP, Fedak MA, Hindell MA and others (2004) Winter habitat use and foraging behavior of crabeater seals along the Western Antarctic Peninsula. Deep-Sea Res II 51:2279-2303

> Burns JM, Hindell MA, Bradshaw CJA, Costa DP (2008) Fine-scale habitat selection of crabeater seals as determined by diving behavior. Deep-Sea Res II 55: 500-514

> Cherel Y, Hobson KA (2007) Geographical variation in carbon stable isotope signatures of marine predators: a tool to investigate their foraging areas in the Southern Ocean. Mar Ecol Prog Ser 329:281-287

> Cherel Y, Hobson KA, Guinet C, Vanpe C (2007) Stable isotopes document seasonal changes in trophic niches and winter foraging individual specialization in diving predators from the Southern Ocean. J Anim Ecol 76: 826-836

> Cherel Y, Kernaléguen L, Richard P, Guinet C (2009) Whisker isotopic signature depicts migration patterns and multi-year intra- and inter-individual foraging strategies in fur seals. Biol Lett 5:830-832

> Clarke A, Murphy EJ, Meredith MP, King JC, Peck LS, Barnes DKA, Smith RC (2007) Climate change and the marine ecosystem of the western Antarctic Peninsula. Philos Trans R Soc Lond B Biol Sci 362:149-166

Costa DP, Crocker DE (1996) Marine mammals of the Southern Ocean. Antarct Res Ser 70:278-301

Costa DP, Klinck JM, Hofmann EE, Dinniman MS, Burns JM (2008) Upper ocean variability in west Antarctic Peninsula continental shelf waters as measured using instrumented seals. Deep-Sea Res II 55:323-337

Costa DP, Hückstädt LA, Crocker DE, McDonald BI, Goebel ME, Fedak MA (2010) Approaches to studying climatic change and its role on the habitat selection of Antarctic pinnipeds. Integr Comp Biol 50:1018-1030

Crawford K, McDonald RA, Bearhop S (2008) Applications of stable isotope techniques to the ecology of mammals. Mammal Rev 38:87-107

Croxall JP (1992) Southern Ocean environmental changes: effects on seabird, seal and whale populations. Philos Trans R Soc Lond B Biol Sci 338:119-127

> Dalerum F, Angerbjorn A (2005) Resolving temporal variation in vertebrate diets using naturally occurring stable isotopes. Oecologia 144:647-658

> Deniro MJ, Epstein S (1978) Influence of diet on the distribution of carbon isotopes in animals. Geochim Cosmochim Acta 42:495-506

> Ducklow HW, Baker K, Martinson DG, Quetin LB and others (2007) Marine pelagic ecosystems: the West Antarctic Peninsula. Philos Trans R Soc Lond B Biol Sci 362:67-94

Eder EB, Lewis MN, Campagna C, Koch PL (2010) Evidence of demersal foraging from stable isotope analysis of juvenile elephant seals from Patagonia. Mar Mamm Sci 26: 430-442

Erickson AW, Hanson MB, Kerry KR, Hempel G (1990) Continental estimates and population trends of Antarctic ice seals. In: Kerry KR, Hempel G (eds) Antarctic ecosystems: ecological change and conservation. Springer, Heidelberg, p 253-264

Fraser WR, Hofmann EE (2003) A predator's perspective on causal links between climate change, physical forcing and ecosystem response. Mar Ecol Prog Ser 265:1-15
Gales NJ, Fraser WR, Costa DP, Southwell C (2004) Do crabeater seals forage cooperatively? Deep-Sea Res II 51: 2305-2310

Gales N, Barnes J, Chittick B, Gray M, Robinson S, Burns J, Costa D (2005) Effective, field-based inhalation anesthesia for ice seals. Mar Mamm Sci 21:717-727

> Goericke R, Fry B (1994) Variations of marine plankton $\delta^{13} \mathrm{C}$ with latitude, temperature, and dissolved $\mathrm{CO}_{2}$ in the world ocean. Global Biogeochem Cycles 8:85-90

Graham BS, Koch PL, Newsome SD, McMahon K, Aurioles D (2009) Using isoscapes to trace the movements and foraging behavior of top predators in oceanic ecosystems. In: West JB, Bowen GJ, Dawson TE, Tu KP (eds) Isoscapes: understanding movement, pattern, and process on earth through isotope mapping. Springer, Berlin, p 299-318

Greaves DK, Hammill MO, Eddington JD, Pettipas D, Schreer JF (2004) Growth rate and shedding of vibrissae in the gray seal, Halichoerus grypus: a cautionary note for stable isotope diet analysis. Mar Mamm Sci 20: 296-304

> Green K, Williams R (1986) Observations on food remains in faeces of elephant, leopard and crabeater seals. Polar Biol 6:43-45

Hall-Aspland SA, Rogers TL, Canfield RB (2005) Stable carbon and nitrogen isotope analysis reveals seasonal variation in the diet of leopard seals. Mar Ecol Prog Ser 305: 249-259

Hewitt R, Lipsky JD (2009) Krill and other plankton. In: Perrin WF, Wursig B, Thewissen JGM (eds) Encyclopedia of marine mammals. Academic Press, San Diego, CA, p 657-664

> Hewitt RP, Demer DA, Emery JH (2003) An 8-year cycle in krill biomass density inferred from acoustic surveys conducted in the vicinity of the South Shetland Islands during the austral summers of 1991-1992 through 2001-2002. Aquat Living Resour 16:205-213

> Hill SL, Murphy EJ, Reid K, Trathan PN, Constable AJ (2006) Modelling Southern Ocean ecosystems: krill, the food-web, and the impacts of harvesting. Biol Rev Camb Philos Soc 81:581-608

Hirons AC, Schell DM, Finney BP (2001a) Temporal records of $\delta^{13} \mathrm{C}$ and $\delta^{15} \mathrm{~N}$ in North Pacific pinnipeds: inferences regarding environmental change and diet. Oecologia 129:591-601

Hirons AC, Schell DM, St. Aubin DJ (2001b) Growth rates of vibrissae of harbor seals (Phoca vitulina) and Steller sea lions (Eumatopias jubatus). Can J Zool 79:1053-1061

Hobson KA, Schell DM, Renouf D, Noseworthy E (1996) Stable carbon and nitrogen isotopic fractionation between diet and tissues of captive seals: implications for dietary reconstructions involving marine mammals. Can J Fish Aquat Sci 53:528-533

Hofmann EE, Hüsrevoglu YS (2003) A circumpolar modeling study of habitat control of Antarctic krill (Euphausia superba) reproductive success. Deep-Sea Res II 50: 3121-3142

> Hofmann EE, Wiebe PH, Costa DP, Torres JJ (2004) An overview of the Southern Ocean Global Ocean Ecosystems Dynamics program. Deep-Sea Res II 51:1921-1924

> Howard SL, Hyatt J, Padman L (2004) Mixing in the pycnocline over the western Antarctic Peninsula shelf during Southern Ocean GLOBEC. Deep-Sea Res II 51:1965-1979

Hückstädt LA, Koch PL, McDonald BI, Goebel ME, Crocker DE, Costa DP (2012) Stable isotope analyses reveal indi- 
vidual variability in the trophic ecology of a top marine predator, the southern elephant seal. Oecologia 169(2): 395-406

> Jaeger A, Connan M, Richard P, Cherel Y (2010a) Use of stable isotopes to quantify seasonal changes of trophic niche and levels of population and individual specialisation in seabirds. Mar Ecol Prog Ser 401:269-277

> Jaeger A, Lecomte VJ, Weimerskirch H, Richard P, Cherel Y (2010b) Seabird satellite tracking validates the use of latitudinal isoscapes to depict predators' foraging areas in the Southern Ocean. Rapid Commun Mass Spectrom 24: 3456-3460

Kelly JF (2000) Stable isotopes of carbon and nitrogen in the study of avian and mammalian trophic ecology. Can J Zool 78:1-27

Knox GA (2007) Biology of the Southern Ocean. 2nd edn. CRC Press, Boca Raton, FL

Kock KH, Shimadzu Y (1994) Trophic relationships and trends in population-size and reproductive parameters in Antarctic high-level predators. In: El-Sayeck SZ (ed) Southern Ocean ecology: the BIOMASS perspective. Cambridge University Press, Cambridge, p 287-312

> Kurle CM, Gudmundson CJ (2007) Regional differences in foraging of young-of-the-year Steller sea lions Eumetopias jubatus in Alaska: stable carbon and nitrogen isotope ratios in blood. Mar Ecol Prog Ser 342:303-310

Kurle CM, Worthy GAJ (2002) Stable nitrogen and carbon isotope ratios in multiple tissues of the northern fur seal Callorhinus ursinus: implications for dietary and migratory reconstructions. Mar Ecol Prog Ser 236:289-300

> Lascara CM, Hofmann EE, Ross RM, Quetin LB (1999) Seasonal variability in the distribution of Antarctic krill, Euphausia superba, west of the Antarctic Peninsula. Deep-Sea Res I 46:951-984

$>$ Laws RM (1977) Seals and whales of the Southern Ocean. Philos Trans R Soc Lond B Biol Sci 279:81-96

> Lesage V, Hammill MO, Kovacs KM (2002) Diet-tissue fractionation of stable carbon and nitrogen isotopes in phocid seals. Mar Mamm Sci 18:182-193

> Loeb V, Siegel V, Holmhansen O, Hewitt R, Fraser W, Trivelpiece W, Trivelpiece S (1997) Effects of sea-ice extent and krill or salp dominance on the Antarctic food web. Nature 387:897-900

Loeb VJ, Hofmann EE, Klinck JM, Holm-Hansen O, White WB (2009) ENSO and variability of the Antarctic Peninsula pelagic marine ecosystem. Antarct Sci 21:135-148

Lowry LF, Testa JW, Calvert W (1988) Notes on winter feeding of crabeater and leopard seals near the Antarctic Peninsula. Polar Biol 8:475-478

> Lynnes AS, Reid K, Croxall JP (2004) Diet and reproductive success of Adelie and chinstrap penguins: linking response of predators to prey population dynamics. Polar Biol 27:544-554

Marrari M, Daly KL, Hu C (2008) Spatial and temporal variability of SeaWiFS chlorophyll a distributions west of the Antarctic Peninsula: implications for krill production. Deep-Sea Res II 55:377-392

> Martinez del Rio C, Wolf N, Carleton SA, Gannes LZ (2009) Isotopic ecology ten years after a call for more laboratory experiments. Biol Rev Camb Philos Soc 84:91-111

> Matich P, Heithaus MR, Layman CA (2011) Contrasting patterns of individual specialization and trophic coupling in two marine apex predators. J Anim Ecol 80:294-305

McDonald BI, Crocker DE, Burns JM, Costa DP (2008) Body condition as an index of winter foraging success in crabeater seals (Lobodon carcinophaga). Deep-Sea Res II 55:515-522

> Moline MA, Claustre H, Frazer TK, Schofield O, Vernet M (2004) Alteration of the food web along the Antarctic Peninsula in response to a regional warming trend. Glob Change Biol 10:1973-1980

> Moore JW, Semmens BX (2008) Incorporating uncertainty and prior information into stable isotope mixing models. Ecol Lett 11:470-480

> Newland C, Field IC, Cherel Y, Guinet C, Bradshaw CJA, McMahon CR, Hindell MA (2011) Diet of juvenile southern elephant seals reappraised by stable isotopes in whiskers. Mar Ecol Prog Ser 424:247-258

Newsome SD, Tinker MT, Monson DH, Oftedal OT and others (2009) Using stable isotopes to investigate individual diet specialization in California sea otters (Enhydra lutris nereis). Ecology 90:961-974

Newsome SD, Bentall GB, Tinker MT, Oftedal OT, Ralls K, Estes JA, Fogel ML (2010a) Variation in $\delta^{13} \mathrm{C}$ and $\delta^{15} \mathrm{~N}$ diet-vibrissae trophic discrimination factors in a wild population of California sea otters. Ecol Appl 20: 1744-1752

Newsome SD, Clementz MT, Koch PL (2010b) Using stable isotope biogeochemistry to study marine mammal ecology. Mar Mamm Sci 26:509-572

> Paradis E, Claude J, Strimmer K (2004) APE: analyses of phylogenetics and evolution in R language. Bioinformatics 20:289-290

Phillips DL (2001) Mixing models in analyses of diet using multiple stable isotopes: a critique. Oecologia 127: $166-170$

Phillips DL, Newsome SD, Gregg JW (2005) Combining sources in stable isotope mixing models: alternative methods. Oecologia 144:520-527

Pinheiro J, Bates D, DebRoy S, Sarkar D, R Development Core Team (2011) nlme: linear and nonlinear mixed effects models. R package version 3.1-101. Available at http://cran.r-project.org/web/packages/nlme/index.html

Polito MJ, Goebel ME (2010) Investigating the use of stable isotope analysis of milk to infer seasonal trends in the diets and foraging habitats of female Antarctic fur seals. J Exp Mar Biol Ecol 395:1-9

> Polito MJ, Lynch HJ, Naveen R, Emslie SD (2011) Stable isotopes reveal regional heterogeneity in the pre-breeding distribution and diets of sympatrically breeding Pygoscelis spp. penguins. Mar Ecol Prog Ser 421:265-277

Popp BN, Trull T, Kenig F, Wakeham SG and others (1999) Controls on the carbon isotopic composition of Southern Ocean phytoplankton. Global Biogeochem Cycles 13: 827-843

Prezelin BB, Hofmann EE, Mengelt C, Klinck JM (2000) The linkage between Upper Circumpolar Deep Water (UCDW) and phytoplankton assemblages on the west Antarctic Peninsula continental shelf. J Mar Res 58: 165-202

> Quevedo M, Svanback R, Eklov P (2009) Intrapopulation niche partitioning in a generalist predator limits food web connectivity. Ecology 90:2263-2274

Quillfeldt P, McGill RAR, Furness RW (2005) Diet and foraging areas of Southern Ocean seabirds and their prey inferred from stable isotopes: review and case study of Wilson's storm-petrel. Mar Ecol Prog Ser 295:295-304

R Development Core Team (2011) R: a language and environment for statistical computing. R Foundation for Statistical Computing, Vienna. www.R-project.org 
Rau GH, Ainley DG, Bengtson JL, Torres JJ, Hopkins TL (1992) ${ }^{15} \mathrm{~N} /{ }^{14} \mathrm{~N}$ and ${ }^{13} \mathrm{C} /{ }^{12} \mathrm{C}$ in Weddell sea birds, seals, and fish: implications for diet and trophic structure. Mar Ecol Prog Ser 84:1-8

Reiss CS, Cossio AM, Loeb V, Demer DA (2008) Variations in the biomass of Antarctic krill (Euphausia superba) around the South Shetland Islands, 1996-2006. ICES J Mar Sci 65:497-508

Schmidt K, Atkinson A, Stübing D, McClelland JW, Montoya JP, Voss M (2003) Trophic relationships among Southern Ocean copepods and krill: some uses and limitations of a stable isotope approach. Limnol Oceanogr 48:277-289

Semmens BX, Moore JW (2008) MixSIR: a Bayesian stable isotope mixing model. Version 1.0. http://conserver.iugocafe.org/user/brice.semmens/MixSIR

Siegel V, Loeb V (1995) Recruitment of Antarctic krill Euphausia superba and possible causes for its variability. Mar Ecol Prog Ser 123:45-56

Somes CJ, Schmittner A, Galbraith ED, Lehmann MF and others (2010) Simulating the global distribution of nitrogen isotopes in the ocean. Global Biogeochem Cycles 24:GB4019, doi:10.1029/2009GB003767

Southwell C, de la Mare B, Borchers D, Burt L (2004) Shipboard line transect surveys of crabeater seal abundance in the pack-ice off east Antarctica: evaluation of assumptions. Mar Mamm Sci 20:602-620

Stammerjohn SE, Martinson DG, Smith RC, Iannuzzi RA (2008) Sea ice in the western Antarctic Peninsula region: spatio-temporal variability from ecological and climate change perspectives. Deep-Sea Res II 55:2041-2058

Tollit DJ, Wong M, Winship AJ, Rosen DAS, Trites AW (2003) Quantifying errors associated with using prey

Editorial responsibility: Hans Heinrich Janssen, Oldendorf/Luhe, Germany skeletal structures from fecal samples to determine the diet of Steller's sea lion (Eumetopias jubatus). Mar Mamm Sci 19:724-744

> Trathan PN, Forcada J, Murphy EJ (2007) Environmental forcing and Southern Ocean marine predator populations: effects of climate change and variability. Philos Trans R Soc Lond B Biol Sci 362:2351-2365

> Vander Zanden MJ, Rasmussen JB (2001) Variation in $\delta^{15} \mathrm{~N}$ and $\delta^{13} \mathrm{C}$ trophic fractionation: implications for aquatic food web studies. Limnol Oceanogr 46:2061-2066

Vander Zanden MJ, Cabana G, Rasmussen JB (1997) Comparing trophic position of freshwater fish calculated using stable nitrogen isotope ratios $\left(\delta^{15} \mathrm{~N}\right)$ and literature dietary data. Can J Fish Aquat Sci 54:1142-1158

- Wada E, Terazaki M, Kabaya Y, Nemoto T (1987) ${ }^{15} \mathrm{~N}$ and ${ }^{13} \mathrm{C}$ abundances in the Antarctic ocean with emphasis on the biogeochemical structure of the food web. Deep-Sea Res I 34:829-841

Wall SM, Bradshaw CJA, Southwell CJ, Gales NJ, Hindell MA (2007) Crabeater seal diving behaviour in eastern Antarctica. Mar Ecol Prog Ser 337:265-277

> Zhao L, Castellini MA, Mau TL, Trumble SJ (2004) Trophic interactions of Antarctic seals as determined by stable isotope signatures. Polar Biol 27:368-373

- Zhao L, Schell DM, Castellini MA (2006) Dietary macronutrients influence $\delta^{13} \mathrm{C}$ and $\delta^{13} \mathrm{C}$ signatures of pinnipeds: captive feeding studies with harbor seals (Phoca vitulina). Comp Biochem Physiol A Mol Integr Physiol 143: 469-478

Zuur AF, Ieno EN, Walker NJ, Saveliev AA, Smith GM (2009) Mixed effects models and extensions in ecology with R. Springer, New York, NY

Submitted: October 5, 2011; Accepted: January 12, 2012 Proofs received from author(s): May 9, 2012 